\title{
Process Evaluation of Carbon Dioxide Capture for Coal-Fired Power Plants
}

\author{
Satoshi Kodama ${ }^{1}$, Kazuya Goto $^{2}$ \& Hidetoshi Sekiguchi ${ }^{1}$ \\ ${ }^{1}$ Department of Chemical Engineering, Graduate School of Science and Engineering, Tokyo Institute of \\ Technology, Tokyo, Japan \\ ${ }^{2}$ Chemical Research Group, Research Institute of Innovative Technology for the Earth, Kyoto, Japan \\ Correspondence: Satoshi Kodama, Department of Chemical Engineering, Graduate School of Science and \\ Engineering, Tokyo Institute of Technology, 2-12-1-S4-1 Ookayama, Meguro-ku Tokyo, Japan. Tel: \\ 81-3-5734-2135. E-mail: skodama@chemeng.titech.ac.jp
}

Received: December 25, 2013 Accepted: February 15, 2014 Online Published: April 30, 2014

doi:10.5539/eer.v4n2p105 URL: http://dx.doi.org/10.5539/eer.v4n2p105

\begin{abstract}
Carbon capture is a promising technology for carbon dioxide $\left(\mathrm{CO}_{2}\right)$ removal from large stationary $\mathrm{CO}_{2}$ sources. The effects of carbon dioxide capture process on output efficiency of fossil power plants were investigated. Supercritical pulverized coal and integrated coal gasification combined cycle (IGCC) were assumed as model coal-fired power plants for this investigation. Heat-driven and pressure-driven $\mathrm{CO}_{2}$ capture processes such as chemical absorption and physical adsorption were assumed for $\mathrm{CO}_{2}$ capture process. In this study, these technologies were evaluated and compared under the unified basis and conditions by using the commercial process simulator. For IGCC plant, the efficiency penalty by installing water-gas shift reaction was also investigated. Gross and net power generation, efficiency and the efficiency penalty by $\mathrm{CO}_{2}$ capture process were calculated. Heat duty for $\mathrm{CO}_{2}$ capture process and $\mathrm{CO}_{2}$ compression conditions were varied, and those effects on the efficiency penalty were obtained. The results provide a guideline for development of $\mathrm{CO}_{2}$ capture process of power plants.
\end{abstract}

Keywords: carbon dioxide capture, power plant, process simulation

\section{Introduction}

In working group I contribution to the fifth assessment report of the Intergovernmental Panel on Climate Change (IPCC), it is reported that "Warming of the climate system is unequivocal, and since the 1950s, many of the observed changes are unprecedented over decades to millennia" (IPCC, 2013). Several scenarios which reduce the carbon dioxide $\left(\mathrm{CO}_{2}\right)$ emission and stabilize the global climate change are proposed, such as the 450 scenario and the 550 scenario. The 450 scenario can control the average temperature rise within $2{ }^{\circ} \mathrm{C}$ by stabilizing the $\mathrm{CO}_{2}$ concentration in the atmosphere for $450 \mathrm{ppm}$. In the scenario, $14 \mathrm{GT} / \mathrm{y}$ of $\mathrm{CO}_{2}$ emission must be reduced in 2030. To reduce the $\mathrm{CO}_{2}$ emission, it is suggested to use renewable energy, biofuels, nuclear power and carbon capture and storage (CCS), as well as energy saving. CCS is expected to remove $2 \mathrm{GT} / \mathrm{yr}$ of $\mathrm{CO}_{2}$ emission (IEA, 2009). $\mathrm{CO}_{2}$ is generated by various human activities, such as electricity and heat producing, manufacturing, transport etc. The $\mathrm{CO}_{2}$ from electricity and heat generation and manufacturing are typically emitted from large exhaust stacks, and they can be described as large stationary sources. The large stationary sources represent potential opportunities for the addition of $\mathrm{CO}_{2}$ capture plants. The properties of each $\mathrm{CO}_{2}$-containing gas is different, while the $\mathrm{CO}_{2}$ partial pressure is important for $\mathrm{CO}_{2}$ capture. Coal for power generation is primarily burnt in pulverized-coal (PC) boilers producing an atmospheric pressure flue gas stream with a $\mathrm{CO}_{2}$ partial pressure of up to $0.014 \mathrm{MPa}$. The newer and potentially more efficient integrated coal gasification combined cycle (IGCC) technology has been developed, and $\mathrm{CO}_{2}$ partial pressure of $\mathrm{CO}_{2}$ capture target gas is up to 0.014 $\mathrm{MPa}$ (post combustion) or $1.4 \mathrm{MPa}$ (pre combustion) (IPCC, 2005).

There are several $\mathrm{CO}_{2}$ captuure technologies, which use sorbent, solvent or membranes etc. The technologies are also classified as heat and/or pressure driven process. For example, absorption by chemical solvents and temperature swing adsorption are a heat driven process. On the other hand, the physical absorption of physical solvents, pressure swing adsorption and membrane separation are a pressure driven process. Generally, heat-driven $\mathrm{CO}_{2}$ capture is used for low $\mathrm{CO}_{2}$ partial pressure on target gas, while pressure-driven process is used 
for higher $\mathrm{CO}_{2}$ partial pressure. The combination of heat and pressure-driven $\mathrm{CO}_{2}$ capture process such as MDEA process is also evaluated. From the point of view of development of $\mathrm{CO}_{2}$ capture process, it is important to estimate the efficiency penalty of power plants. There are many studies which analyze the effect of operating conditions of $\mathrm{CO}_{2}$ capture process on power plant efficiency (Abu Zhara, 2011; Cifre, 2009; Goto, 2013; Strube, 2011). However, the relationship between heat and energy duty of $\mathrm{CO}_{2}$ capture process and compressors on the efficiency of the power plants is not cleared yet.

In this study, PC and IGCC power plants were modelled by using a process simulator. The effect of properties of $\mathrm{CO}_{2}$ capture process on power plant efficiency was investigated under the unified basis and conditions, such as coal property, efficiency of compressors or pumps etc. For IGCC plant, the efficiency penalty by installing water-gas shift reaction was also investigated. Gross and net power generation, efficiency and the efficiency penalty by $\mathrm{CO}_{2}$ capture process were calculated. Heat duty for $\mathrm{CO}_{2}$ capture process and $\mathrm{CO}_{2}$ compression conditions were varied, and those effects on the efficiency penalty were obtained.

\section{Development of Process Simulation Models}

A commercial process simulator Aspen Plus 7.3 was used for the process modelling of power plants. The design basis of PC and IGCC power plant was referred from literature (NETL, 2007). The design coal was bituminous (Illinois No. 6) as shown in the reference. The high heat value (HHV) and low heat value (LHV) of the coal is $27,113 \mathrm{KJ} / \mathrm{kg}$ and $26,151 \mathrm{KJ} / \mathrm{kg}$, respectively.

\subsection{PC Power Plant}

For the development of PC power plant with $\mathrm{CO}_{2}$ removal, "Case12 PC with supercritical case" in the NETL report was referred (NETL, 2007). Process flow diagram of the PC power plant is shown in Figure 1. Pulverized coal was supplied to the burner. In this burner, steam was generated and was supplied to steam turbines. The steam turbines consist of high-pressure (HP), intermediate-pressure (IP) and low-pressure (LP) turbines as shown in Figure 2. The steam temperature generated by the heater was $593{ }^{\circ} \mathrm{C}$ and the pressure of superheated steam was 24.1 MPa. The flue gas from the burner was treated by selective catalytic reduction (SCR), bag filter and flue gas desulfurization (FGD). Finally, $\mathrm{CO}_{2}$ was removed from the gas and treated flue gas was released from the stack. The separated $\mathrm{CO}_{2}$ was compressed and liquefied by compressors to sequestration-ready pressure, 15.2 MPa. The details of $\mathrm{CO}_{2}$ compression process and steam turbines are described in 2.3 and 2.4.

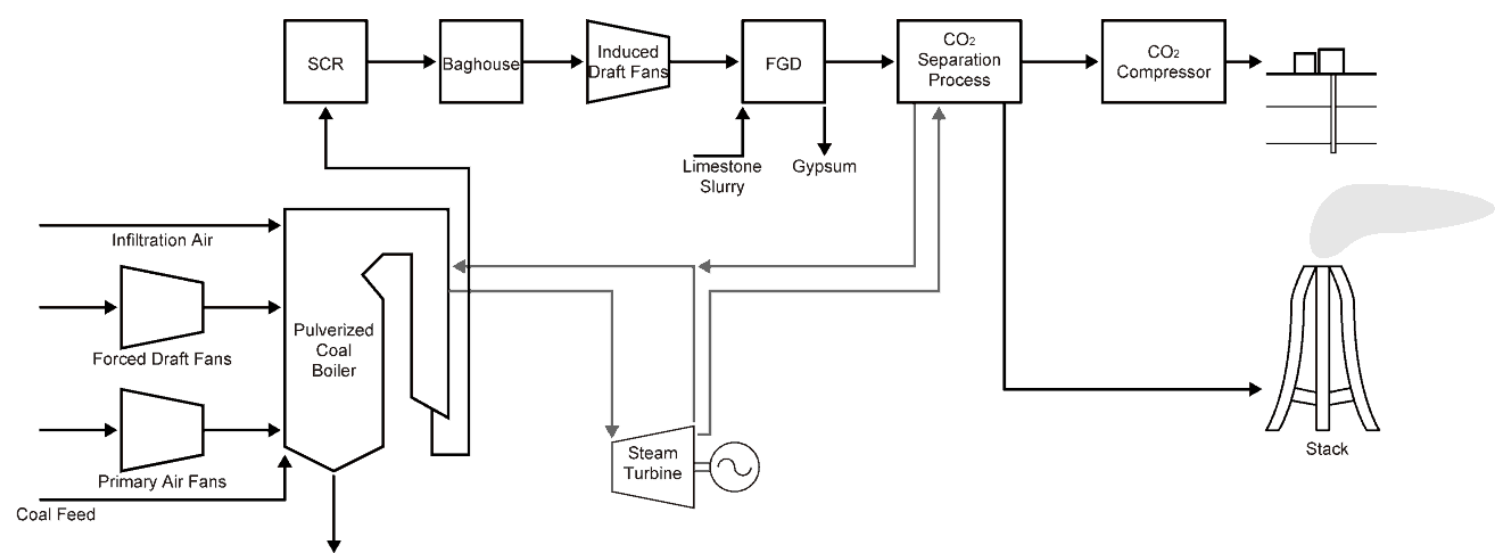

Figure 1. Process flow diagram of $\mathrm{PC}$ power plant with $\mathrm{CO}_{2}$ post-combustion capture (Case12 in the literature (NETL, 2007)) 


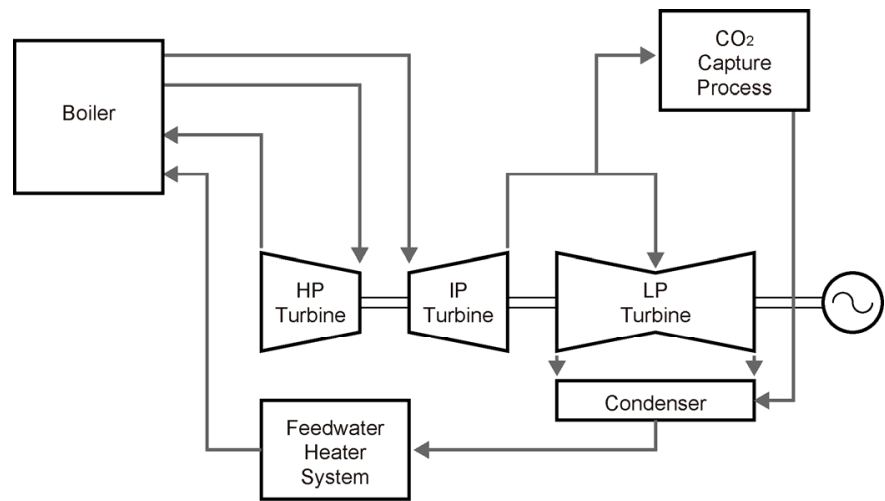

Figure 2. Steam extraction from steam turbines to $\mathrm{CO}_{2}$ capture process

\subsection{IGCC Power Plant}

\subsubsection{IGCC Without $\mathrm{CO}_{2}$ Capture}

Process flow diagram of the IGCC power plant is shown in Figure 3. Coal was supplied to gasifier and transferred to $\mathrm{CO}$ and $\mathrm{H}_{2}$. The gas was treated by de-SOx reactor and burned in gas turbine engine. The gas turbine engine drove electric generator. The flue gas from the gas turbine was sent to heat recovery steam generator (HRSG) and generate steam which drove steam turbines. The steam temperature from the heater was $538^{\circ} \mathrm{C}$ and the pressure of superheated steam was $12.4 \mathrm{MPa}$. The steam turbines drove electric generators. The fluegas was then sent to stack and emitted to the air.

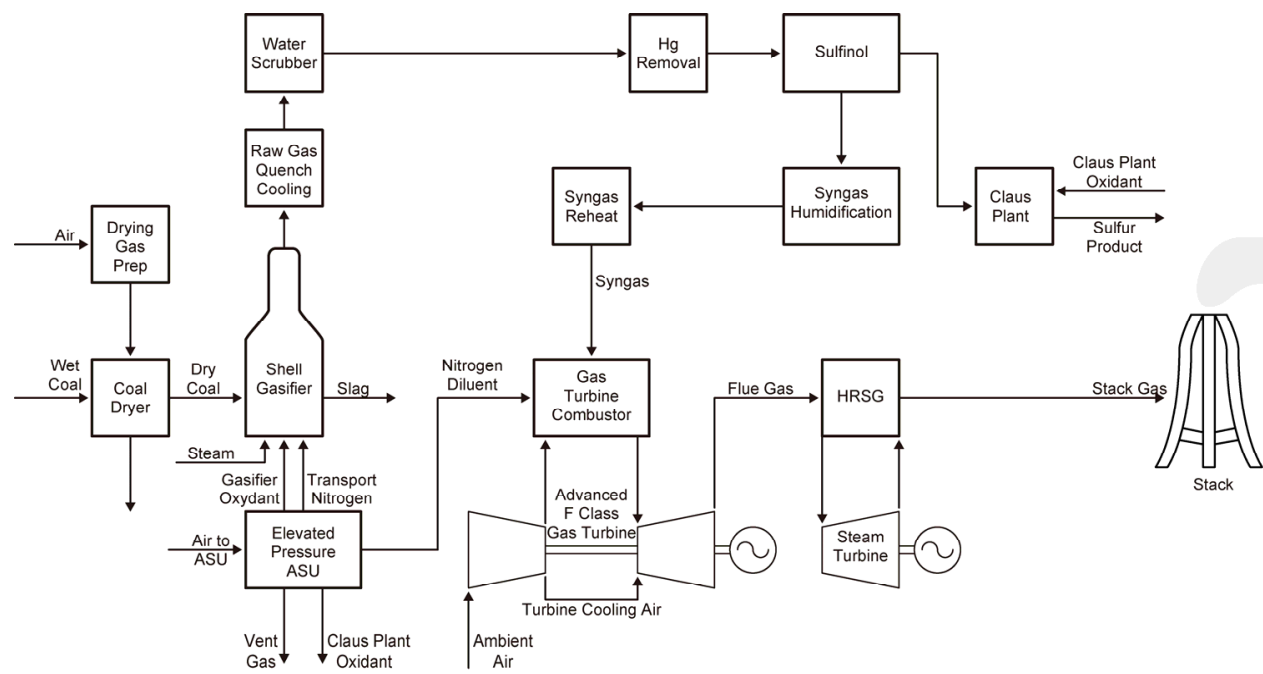

Figure 3. Process flow diagram of IGCC power plant without $\mathrm{CO}_{2}$ capture (Case5 in the literature (NETL, 2007))

\subsubsection{IGCC With $\mathrm{CO}_{2}$ Capture}

Process flow diagram of the IGCC power plant with $\mathrm{CO}_{2}$ capture is shown in Figure 4. For $\mathrm{CO}_{2}$ capture case, gasified coal $\left(\mathrm{CO}\right.$ and $\left.\mathrm{H}_{2}\right)$ was treated by water-gas shift reactor, in which $\mathrm{CO}$ reacted with $\mathrm{H}_{2} \mathrm{O}$ and yielded $\mathrm{CO}_{2}$ and $\mathrm{H}_{2}$. Then $\mathrm{CO}_{2}$ was removed in $\mathrm{CO}_{2}$ capture process (shown as Selexol Unit in Figure 4) and liquefied by compressors. The treated gas was burnt in gas turbine engine, yielding hot flue gas. The flue gas was sent to HRSG. The steam temperature from the heater was $566^{\circ} \mathrm{C}$ and the pressure of superheated steam was $12.5 \mathrm{MPa}$.

Generally $\mathrm{CO}_{2}$ capture from IGCC power plant is performed from the water-shifted gas, and it is called pre-combustion capture. On the other hand, IGCC power plant without $\mathrm{CO}_{2}$ capture process does not contain water-shift reactor. In this study, post-combustion capture from such process was also estimated. $\mathrm{CO}_{2}$ partial pressure before $\mathrm{CO}_{2}$ capture is $1.2 \mathrm{MPa}$ for pre-combustion process and $0.0076 \mathrm{MPa}$ for post-combustion process. 


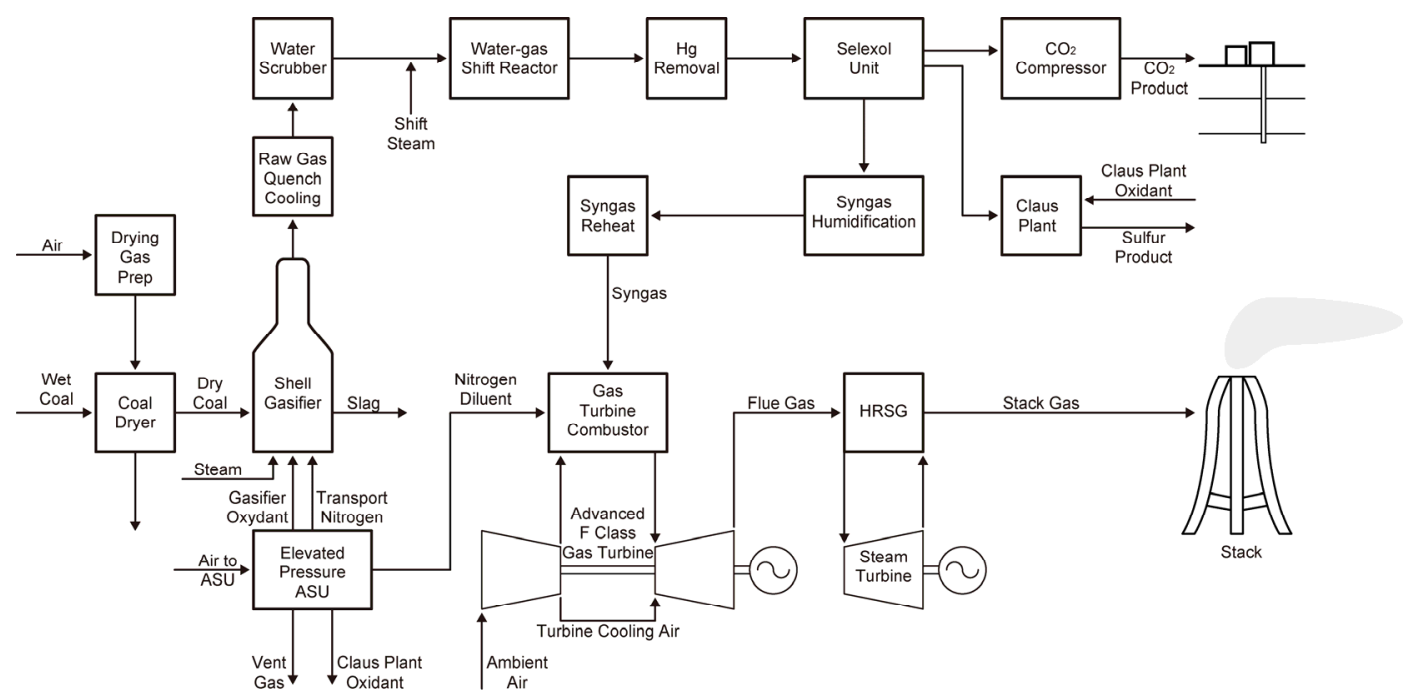

Figure 4. Process flow diagram of IGCC power plant with $\mathrm{CO}_{2}$ capture (Case6 in the literature (NETL, 2007))

\section{$2.3 \mathrm{CO}_{2}$ Capture Process}

\subsubsection{Heat-Driven $\mathrm{CO}_{2}$ Capture Process}

Chemical absorption solvent or temperature swing adsorption (TSA) process was estimated for the $\mathrm{CO}_{2}$ capture process and was driven by applying heat to the sorbents. In this study, the detailed reaction in $\mathrm{CO}_{2}$ capture process such as the reaction of $\mathrm{CO}_{2}$ with chemical solvents or adsorbents was not considered. It was estimated that $\mathrm{CO}_{2}$ was separated by applying some amount of heat. The provided heat is consumed for reactions, temperature increase, steam generation, and so on. In this study, such a breakdown was not considered and a total heat requirement was considered for sensitivity analysis. The heat required for $\mathrm{CO}_{2}$ capture was supplied by bypassing steam from the inlet of LP turbine. The steam was estimated to be cooled to $110{ }^{\circ} \mathrm{C}$ in the $\mathrm{CO}_{2}$ capture process. $90 \%$ (for $\mathrm{PC}$ ) or $95 \%$ (for IGCC) of $\mathrm{CO}_{2}$ from the flue gas was captured. $\mathrm{CO}_{2}$ was flashed in $0.16 \mathrm{MPa}$ from $\mathrm{CO}_{2}$ capture process and sent to $\mathrm{CO}_{2}$ compressor.

\subsubsection{Pressure-Driven $\mathrm{CO}_{2}$ Capture Process}

Physical absorption solvent, pressure swing adsorption (PSA) and membrane separation process are $\mathrm{CO}_{2}$ capture process driven by pressure difference. In this process, detailed separation mechanism in $\mathrm{CO}_{2}$ capture process such as $\mathrm{CO}_{2}$ absorption, adsorption or membrane transparent was not considered and the outlet pressure of $\mathrm{CO}_{2}$ capture process was considered as well as that of heat-driven $\mathrm{CO}_{2}$ capture system. The pressure difference was generated by a pump or compressor driven by electricity generated at the power plant, and was combined with $\mathrm{CO}_{2}$ compression process.

\subsubsection{Heat and Pressure-Driven $\mathrm{CO}_{2}$ Capture Process}

In heat-driven $\mathrm{CO}_{2}$ capture process, $\mathrm{CO}_{2}$ was released under higher partial pressure than that of $\mathrm{CO}_{2}$ source. It is expected that combination of $\mathrm{CO}_{2}$ capture process operated by heat and pressure may reduce the efficiency penalty. Parametric study of heat required to separate $\mathrm{CO}_{2}$ and inlet pressure on $\mathrm{CO}_{2}$ compressor on efficiency penalty of the power plant was carried out from the results obtained in 2.3.1 and 2.3.2.

\section{$2.4 \mathrm{CO}_{2}$ Compression}

$\mathrm{CO}_{2}$ separated in the $\mathrm{CO}_{2}$ capture process was pressurized to $15.2 \mathrm{MPa}$, so that it could be transferred to the sequestration site by pipeline. $\mathrm{CO}_{2}$ compressors were connected in series as shown in Figure 5. The compression conditions are listed in Table 1, which were also referred from a literature (NETL, 2007). The compressed $\mathrm{CO}_{2}$ was cooled to $52{ }^{\circ} \mathrm{C}\left(125^{\circ} \mathrm{F}\right)$ between each compressor except the first and second stage $\left(32^{\circ} \mathrm{C}\right.$ or $\left.90{ }^{\circ} \mathrm{F}\right)$. The power consumption of the first stage was smaller than the other compressors because it worked as a liquid pump. For the conditions that the inlet pressure was lower than $0.16 \mathrm{MPa}$, additional compressors were added so that the pressure difference of inlet and outlet would be less than 2.2 times. 
Table 1. Outlet pressure for each stage of $\mathrm{CO}_{2}$ compression process

\begin{tabular}{cc}
\hline Stage & Outlet pressure $(\mathrm{MPa})$ \\
\hline 1 & 15.3 \\
2 & 8.27 \\
3 & 3.76 \\
4 & 1.71 \\
5 & 0.78 \\
6 & 0.36 \\
\hline
\end{tabular}

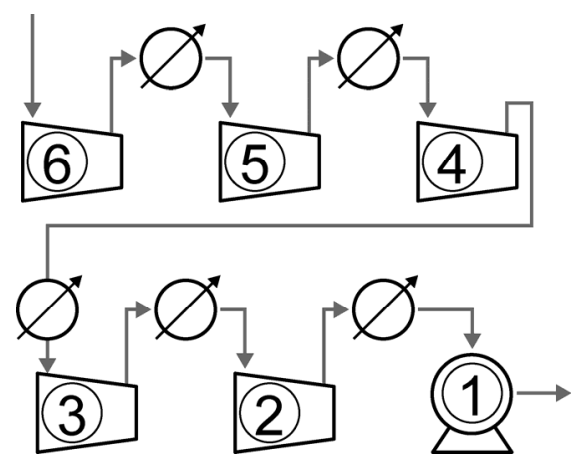

Figure 5. Configuration of $\mathrm{CO}_{2}$ compression process

The relation between $\mathrm{CO}_{2}$ inlet pressure $P_{\mathrm{CO} 2}[\mathrm{MPa}]$ and compression energy per $\mathrm{CO}_{2}$ mass $w_{\mathrm{CO} 2}\left[\mathrm{~kW} / \mathrm{t}-\mathrm{CO}_{2}\right]$ is shown in Figure 6. It shows good relation to semi-log plot and the fitting result is shown in Equation (1).

$$
w_{\mathrm{CO} 2}=-26.37 \ln \left(P_{\mathrm{CO} 2}\right)+58.16
$$

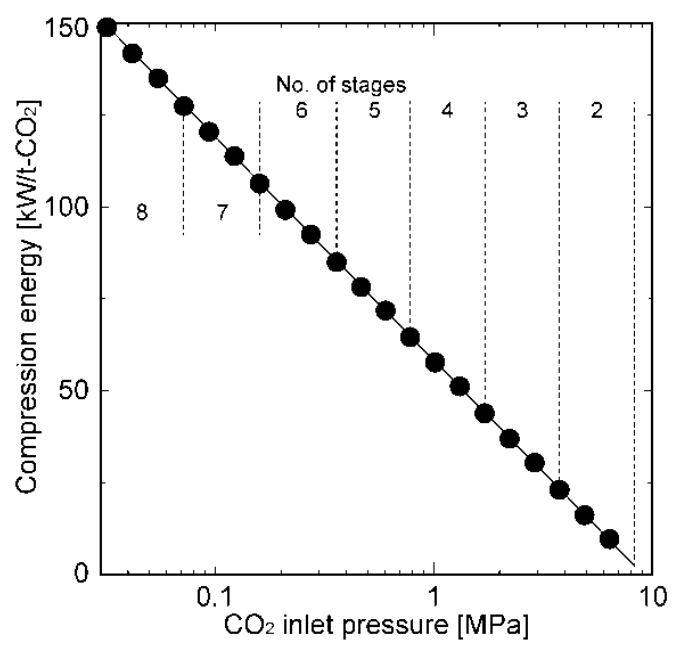

Figure 6. Relation between $\mathrm{CO}_{2}$ inlet pressure $\left(P_{\mathrm{CO} 2}\right)$ and compression energy $\left(w_{\mathrm{CO} 2}\right)$, outlet pressure $=15.2$ [MPa]

\subsection{Variations of Process Model Calculation}

Power generation and efficiency of the power plants were calculated and verified with reference data. Generated power $W[\mathrm{~kW}]$ and efficiency $\eta$ (net, gross) [\%] are calculated by following equations:

$$
\dot{W}_{\text {net }}=\dot{W}_{\text {gross }}-\dot{W}_{\text {aux }}
$$




$$
\begin{gathered}
\eta_{\text {gross }}=\left(\dot{W}_{\text {gross }} \times 3.6\right) / \dot{Q}_{\text {coal }} \times 100 \\
\eta_{\text {net }}=\left(\dot{W}_{\text {net }} \times 3.6\right) / \dot{Q}_{\text {coal }} \times 100
\end{gathered}
$$

Where $\dot{Q}_{\text {coal }}$ is thermal input to the plant by coal combustion $[\mathrm{GJ} / \mathrm{h}], 3.6$ is a conversion factor from $\mathrm{kW}$ to $\mathrm{GJ} / \mathrm{h}$. $\mathrm{CO}_{2}$ recovery ratio was $90 \%$ for PC case and $95 \%$ for IGCC cases, therefore

$$
\dot{m}_{\text {CO2-sep }}=0.90 \dot{m}_{\mathrm{CO} 2 \text {-gen }}\left(\text { for PC), } \dot{m}_{\mathrm{CO} 2 \text {-sep }}=0.95 \dot{m}_{\mathrm{CO} 2 \text {-gen }}\right. \text { (for IGCC) }
$$

The data are shown in Tables 2-4. It was confirmed that the calculated data show good agreement with those

\begin{tabular}{|c|c|c|c|}
\hline & Reference (Case 12) & This study & w/o CCS \\
\hline Coal feed $[\mathrm{t} / \mathrm{h}]\left(\dot{m}_{\text {coal }}\right)$ & 266.090 & 266.090 & 266.090 \\
\hline Thermal input, LHV $[\mathrm{GJ} / \mathrm{h}]\left(\dot{Q}_{\text {.coal }}\right)$ & $6,958,520$ & $6,958,520$ & $6,958,520$ \\
\hline Gross power $[\mathrm{kW}]\left(\dot{W}_{\text {gross }}\right)$ & 663,445 & 673,181 & 797,924 \\
\hline Aux power $[\mathrm{kW}]\left(\dot{W}_{a u x}\right)$ & 117,450 & 114,212 & 63,860 \\
\hline Net power $[\mathrm{kW}]\left(\dot{W}_{n e t}\right)$ & 545,995 & 558,969 & 734,064 \\
\hline Gross efficiency $[\%]\left(\eta_{\text {gross }}\right)$ & 34.3 & 34.8 & 41.3 \\
\hline Net efficiency $[\%]\left(\eta_{n e t}\right)$ & 28.2 & 28.9 & 38.0 \\
\hline $\mathrm{CO}_{2}$ generated $[\mathrm{t} / \mathrm{h}]\left(\dot{m}_{\mathrm{CO} 2 \text {-gen }}\right)$ & 631.1 & 622.7 & 622.7 \\
\hline $\mathrm{CO}_{2}$ separated $[\mathrm{t} / \mathrm{h}]\left(\dot{m}_{\mathrm{CO} 2 \text {-sep }}\right)$ & 568.1 & 560.4 & - \\
\hline Heat duty for $\mathrm{CO}_{2}$ capture $[\mathrm{GJ} / \mathrm{h}]\left(\dot{Q}_{\text {cap }}\right)$ & 2,067 & 2,067 & - \\
\hline Heat duty for $\mathrm{CO}_{2}$ capture per $\mathrm{CO}_{2}$ mass $[\mathrm{GJ} / \mathrm{t}]\left(q_{\text {cap }}\right)$ & 3.64 & 3.64 & - \\
\hline
\end{tabular}
reference data (NETL, 2007).

Table 2. Reference conditions and calculation results for $\mathrm{PC}$ with post-combustion $\mathrm{CO}_{2}$ capture case

Table 3. Reference conditions and calculation results for IGCC case without $\mathrm{CO}_{2}$ capture

\begin{tabular}{lcc}
\hline & Reference $($ Case 5) & This study \\
\hline Coal feed [t/h] $\left(\dot{m}_{\text {coal }}\right)$ & 205.305 & 205.305 \\
Thermal input, LHV $[\mathrm{GJ} / \mathrm{h}]\left(\dot{Q}_{\text {coal }}\right)$ & $5,368,931$ & $5,368,930$ \\
Gross power $[\mathrm{kW}]\left(\dot{W}_{\text {gross }}\right)$ & 748,020 & 730,640 \\
Aux load $[\mathrm{kW}]\left(\dot{W}_{\text {aux }}\right)$ & 112,170 & 102,012 \\
Net power $[\mathrm{kW}]\left(\dot{W}_{\text {net }}\right)$ & 635,850 & 628,628 \\
Gross efficiency $[\%]\left(\eta_{\text {gross }}\right)$ & 50.2 & 49.0 \\
Net efficiency $[\%]\left(\eta_{\text {net }}\right)$ & 42.6 & 42.2 \\
$\mathrm{CO}_{2}$ generated $[\mathrm{t} / \mathrm{h}]\left(\dot{m}_{C O 2-\text { gen }}\right)$ & 455.2 & 459.1 \\
$\mathrm{CO}_{2}$ captured $[\mathrm{t} / \mathrm{h}]\left(\dot{m}_{C O 2}\right)$ & 0 & 0 \\
$\mathrm{Heat}_{\text {duty for } \mathrm{CO}}$ capture $[\mathrm{GJ} / \mathrm{h}]\left(\dot{Q}_{\text {cap }}\right)$ & 0 & 0 \\
Heat duty for $\mathrm{CO}_{2}$ capture per $\mathrm{CO}{ }_{2}$ mass $[\mathrm{GJ} / \mathrm{t}]\left(q_{\text {cap }}\right)$ & 0 & 0 \\
\hline
\end{tabular}


Table 4. Reference conditions and calculation results for IGCC case with pre-combustion $\mathrm{CO}_{2}$ capture

\begin{tabular}{lccc}
\hline & Reference (Case 6) & This study & w/o CCS \\
\hline Coal feed [t/h] $\left(\dot{m}_{\text {coal }}\right)$ & 214.629 & 214.606 & 214,606 \\
Thermal input, $\mathrm{LHV}[\mathrm{GJ} / \mathrm{h}]\left(\dot{Q}_{\text {coal }}\right)$ & $5,612,763$ & $5,612,170$ & $5,612,170$ \\
Gross power $[\mathrm{kW}]\left(\dot{W}_{\text {gross }}\right)$ & 693,555 & 675,845 & 675,845 \\
Aux load $[\mathrm{kW}]\left(\dot{W}_{\text {aux }}\right)$ & 176,420 & 166,359 & 142,071 \\
Net power $[\mathrm{kW}]\left(\dot{W}_{\text {net }}\right)$ & 517,135 & 509,486 & 533,774 \\
Gross efficiency $[\%]\left(\eta_{\text {gross }}\right)$ & 44.5 & 43.4 & 43.4 \\
Net efficiency $[\%]\left(\eta_{\text {net }}\right)$ & 33.2 & 32.7 & 34.2 \\
$\mathrm{CO}_{2}$ generated $[\mathrm{t} / \mathrm{h}]\left(\dot{m}_{\mathrm{CO} 2 \text {-gen }}\right)$ & 477.0 & 479.2 & 479.2 \\
$\mathrm{CO}_{2}$ captured $[\mathrm{t} / \mathrm{h}]\left(\dot{m}_{\mathrm{CO} 2}\right)$ & 453.3 & 455.3 & 0 \\
$\mathrm{Heat}$ duty for $\mathrm{CO}_{2}$ capture $[\mathrm{GJ} / \mathrm{h}]\left(\dot{Q}_{\text {cap }}\right)$ & 0 & 0 & 0 \\
$\mathrm{Heat}$ duty for $\mathrm{CO}_{2}$ capture per $\mathrm{CO}_{2}$ mass $[\mathrm{GJ} / \mathrm{t}]\left(q_{\text {cap }}\right)$ & 0 & 0 & 0 \\
\hline
\end{tabular}

\section{Results}

\section{1 $\mathrm{CO}_{2}$ Capture Energy (Heat)}

\subsubsection{PC Power Plant}

The effect of steam extraction on efficiency of PC power plant was estimated. The steam conditions which entered to LP turbine was $414.9^{\circ} \mathrm{C}, 0.949 \mathrm{MPa}, 1,980,000 \mathrm{~kg} / \mathrm{h}$ and its enthalpy $\dot{H}_{L P-i n}$ was $-25,003 \mathrm{GJ} / \mathrm{h}$. The enthalpy will be $-30,631 \mathrm{GJ} / \mathrm{h}$ when it was supplied to $\mathrm{CO}_{2}$ capture process and cooled to $110{ }^{\circ} \mathrm{C}\left(\dot{H}_{110}\right)$. Thus the maximum $\mathrm{CO}_{2}$ capture energy to the $\mathrm{CO}_{2}$ capture process $\left(\dot{Q}_{\text {cap-max }}\right)$ was calculated as;

$$
\dot{Q}_{\text {cap-max }}=\dot{H}_{L P-i n}-\dot{H}_{110}=5,628 \mathrm{GJ} / \mathrm{h}
$$

$\mathrm{CO}_{2}$ recovered amount $\left(\dot{m}_{\mathrm{CO} 2}\right)$ of this condition was $568.6 \mathrm{t} / \mathrm{h}$, from Table 2 . Therefore, maximum $\mathrm{CO}_{2}$ capture energy per $\mathrm{CO}_{2}$ weight $q_{\text {cap-max }}\left[\mathrm{GJ} / \mathrm{t}-\mathrm{CO}_{2}\right]$ is;

$$
q_{\text {cap-max }}=\dot{Q}_{\text {cap-max }} / \dot{m}_{\text {CO2-sep }}=9.90 \mathrm{GJ} / \mathrm{t}-\mathrm{CO}_{2}
$$

Power generation by an LP turbine $\left(\dot{W}_{\text {gen }}\right)$ was $339,160 \mathrm{~kW}$, and it was $17.5 \%$ of total thermal input to this process $\left(\dot{Q}_{\text {coal }}=6,958,520[\mathrm{GJ} / \mathrm{h}]=1,932,922[\mathrm{~kW}], \mathrm{LHV}\right)$.

Efficiency penalty $\Delta \eta$ [\%-point] was defined as the difference between the net efficiency with $\left(\eta_{\text {net-w/CO2cap }}\right)$ and without $\mathrm{CO}_{2}$ capture process $\left(\eta_{\text {net-w/o CO2cap }}\right)$. In this condition, $\Delta \eta$ was $17.5 \%$ when heat duty for $\mathrm{CO}_{2}$ capture was $9.90 \mathrm{GJ} / \mathrm{t}-\mathrm{CO}_{2}$. The calculations are summarized in Table 5. From the calculation results obtained above, the relation between $\mathrm{CO}_{2}$ capture energy per $\mathrm{CO}_{2}$ mass $\left(q_{c a p}\right)$ and efficiency penalty $(\Delta \eta[\%])$ was calculated as following equation;

$$
\Delta \eta=\left(\Delta \eta_{\max } / q_{\text {cap-max }}\right) \cdot q_{c a p}=1.75 q_{\text {cap }}
$$

Table 5. Steam and $\mathrm{CO}_{2}$ capture conditions for PC power plant

\begin{tabular}{lc}
\hline Stream & LP inlet \\
\hline Enthalpy $[\mathrm{GJ} / \mathrm{h}]\left(\dot{H}_{L P-i n}\right)$ & $-25,003$ \\
Enthalpy at $110{ }^{\circ} \mathrm{C}[\mathrm{GJ} / \mathrm{h}]\left(\dot{H}_{110}\right)$ & $-30,631$ \\
Maximum heat duty for $\mathrm{CO}_{2}$ capture $[\mathrm{GJ} / \mathrm{h}]\left(\dot{Q}_{\text {cap-max }}\right)$ & 5,628 \\
Maximum heat duty for $\mathrm{CO}_{2}$ capture per $\mathrm{CO}_{2}$ mass $\left[\mathrm{GJ} / \mathrm{t}-\mathrm{CO}_{2}\right]\left(q_{\text {cap-max }}\right)$ & 10.0 \\
Power generation by steam turbine $[\mathrm{kW}]\left(\dot{W}_{\text {gen }}\right)$ & 339,160 \\
Maximum efficiency penalty $[\%]\left(\Delta \eta_{\max }\right)$ & $17.5 \%$ \\
Constant of proportionality & 1.75 \\
\hline
\end{tabular}




\subsubsection{IGCC Power Plant (Post-Combustion)}

The effect of steam extraction on efficiency for post-combustion $\mathrm{CO}_{2}$ capture for IGCC power plant (i.e., without water-gas shift reactor) was also examined, and the results are shown in Table 6. As shown in the table, the maximum $\mathrm{CO}_{2}$ capture energy was $1,833 \mathrm{GJ} / \mathrm{h}$ under this condition. $\mathrm{The} \mathrm{CO}_{2}$ generation was $453.3 \mathrm{t} / \mathrm{h}$ from Table 3, therefore maximum $\mathrm{CO}_{2}$ capture energy per $\mathrm{CO}_{2}$ mass was $4.12 \mathrm{GJ} / \mathrm{t}-\mathrm{CO}_{2}$. If the heat duty exeed the value, steam should be supplied from the inlet of IP turbine. When steam is supplied from the inlet of IP turbine, maximum $\mathrm{CO}_{2}$ capture energy per $\mathrm{CO}_{2}$ mass is $4.95 \mathrm{GJ} / \mathrm{t}-\mathrm{CO}_{2}$.

Table 6. Steam and $\mathrm{CO}_{2}$ capture conditions for IGCC power plant with post-combustion $\mathrm{CO}_{2}$ capture process

\begin{tabular}{lcc}
\hline Stream & IP inlet & LP inlet \\
\hline Enthalpy $[\mathrm{GJ} / \mathrm{h}](\dot{H})$ & $-7,327$ & $-7,649$ \\
Enthalpy at $110{ }^{\circ} \mathrm{C}[\mathrm{GJ} / \mathrm{h}]\left(\dot{H}_{110}\right)$ & $-9,481$ & $-9,482$ \\
Maximum heat duty for $\mathrm{CO}_{2}$ capture $[\mathrm{GJ} / \mathrm{h}]\left(\dot{Q}_{\text {cap-max }}\right)$ & 2,154 & 1,833 \\
Maximum heat duty for $\mathrm{CO}_{2}$ capture per $\mathrm{CO}_{2}$ mass $\left(q_{\text {cap-max }}\right)$ & 4.94 & 4.20 \\
Power generation by steam turbine $[\mathrm{kW}]\left(\dot{W}_{\text {gen }}\right)$ & 202,025 & 112,884 \\
Efficiency penalty $[\%](\Delta \eta)$ & 13.5 & 7.57 \\
Constant of proportionality & 2.74 & 1.80 \\
\hline
\end{tabular}

In this condition, the relation between $\mathrm{CO}_{2}$ capture energy per $\mathrm{CO}_{2}$ mass $\left(q_{\text {cap }}\left[\mathrm{GJ} / \mathrm{t}-\mathrm{CO}_{2}\right]\right)$ and efficiency penalty $(\Delta \eta[\%])$ is given by following equations.

$$
\begin{gathered}
\Delta \eta=1.80 q_{\text {cap }} \quad\left(0 \leq q_{\text {cap }} \leq 4.20\right) \\
\Delta \eta=2.74 q_{\text {cap }} \quad\left(4.20<q_{\text {cap }} \leq 4.94\right)
\end{gathered}
$$

\subsubsection{IGCC Power Plant (Pre-Combustion)}

$\mathrm{CO}_{2}$ capture from pre-combustion $\mathrm{CO}_{2}$ capture from IGCC (i.e., with water-gas shift reactor) was considered. Calculation results are shown in Table 7. The power generated in steam turbines was smaller than that of the post-combustion case because water-gas shift reactor consumes energy.

Table 7. Steam and $\mathrm{CO}_{2}$ capture conditions for IGCC power plant with pre-combustion $\mathrm{CO}_{2}$ capture process

\begin{tabular}{lcc}
\hline Stream & IP inlet & LP inlet \\
\hline Enthalpy $[\mathrm{GJ} / \mathrm{h}](\dot{H})$ & $-5,880$ & $-6,128$ \\
Enthalpy at $110{ }^{\circ} \mathrm{C}[\mathrm{GJ} / \mathrm{h}]\left(\dot{H}_{110}\right)$ & $-7,287$ & $-7,287$ \\
Maximum heat duty for $\mathrm{CO}_{2}$ capture $[\mathrm{GJ} / \mathrm{h}]\left(\dot{Q}_{\text {cap-max }}\right)$ & 1,406 & 1,159 \\
Maximum heat duty for $\mathrm{CO}_{2}$ capture per $\mathrm{CO}_{2}$ mass $\left(q_{\text {cap-max }}\right)$ & 2.93 & 2.41 \\
Power generation by steam turbine $[\mathrm{kW}]\left(\dot{W}_{\text {gen }}\right)$ & 156,528 & 87,852 \\
Efficiency penalty $[\%](\Delta \eta)$ & 10.0 & 5.64 \\
Constant of proportionality & 3.42 & 2.33 \\
\hline
\end{tabular}

In this condition, the relation between $\mathrm{CO}_{2}$ capture energy per $\mathrm{CO}_{2}$ mass $\left(q_{\text {cap }}\left[\mathrm{GJ} / \mathrm{t}-\mathrm{CO}_{2}\right]\right)$ and efficiency penalty $(\Delta \eta[\%$-point $]$ ) is given by following equations.

$$
\begin{gathered}
\Delta \eta=2.33 q_{\text {cap }}\left(0 \leq q_{\text {cap }} \leq 2.41\right) \\
\Delta \eta=3.42 q_{\text {cap }}\left(2.41<q_{\text {cap }} \leq 2.93\right)
\end{gathered}
$$




\section{2 $\mathrm{CO}_{2}$ Capture Energy (Pressure)}

As discussed in 2.4, there is a linear semi-log relation between $\mathrm{CO}_{2}$ compression energy and $\mathrm{CO}_{2}$ inlet pressure to the compression process. The $\mathrm{CO}_{2}$ compression energy $w_{\mathrm{CO} 2}$ can be converted to efficiency penalty $\Delta \eta$ for PC and IGCC (post and pre-combustion $\mathrm{CO}_{2}$ capture) processes by following equation.

$$
\Delta \eta=w_{\mathrm{CO} 2} \times\left(\dot{m}_{\mathrm{CO} 2} / \dot{\varphi}_{\text {coal }}\right) \times 100
$$

The y-axis intercept and constant of proportionality of Equation (1) are converted as shown in Table 8.

Table 8. Slopes and y-intercepts of the relation between $\mathrm{CO}_{2}$ inlet pressure $P_{\mathrm{CO} 2}$ and compression energy $w_{\mathrm{CO} 2}$ for PC and IGCCpower plants

\begin{tabular}{ccc}
\hline & Slope & y-intercept \\
\hline PC with post-combustion $\mathrm{CO}_{2}$ capture & -0.765 & 1.69 \\
IGCC with post-combustion $\mathrm{CO}_{2}$ capture & -0.771 & 1.70 \\
IGCC with pre-combustion $\mathrm{CO}_{2}$ capture & -0.770 & 1.70 \\
\hline
\end{tabular}

\section{Discussion}

\section{$4.1 \mathrm{CO}_{2}$ Capture Energy (Combination of Heat and Pressure)}

The results obtained in 3.1 and 3.2 were combined and the efficiency penalty $(\Delta \eta)$ was obtained as a function of $\mathrm{CO}_{2}$ capture energy $\left(q_{\text {cap }}\right)$ and $\mathrm{CO}_{2}$ inlet pressure for compressors $\left(P_{\mathrm{CO} 2}\right)$. For PC with post-combustion $\mathrm{CO}_{2}$ capture, the relation was obtained from Equation (8) and Table 8, and is expressed as Equation (14)

$$
\Delta \eta=1.75 q_{\text {cap }}-0.765 \ln \left(P_{\mathrm{CO} 2}\right)+1.69
$$

The relation is plotted in three-dimensional graph shown in Figure 7.

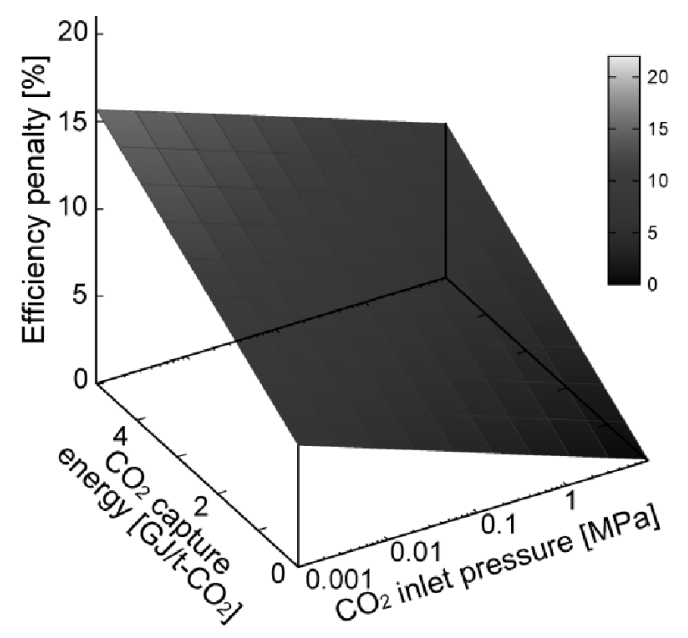

Figure 7. Relation between $\mathrm{CO}_{2}$ capture energy $\left(q_{\text {cap }}\right), \mathrm{CO}_{2}$ inlet pressure for compressors $\left(P_{\mathrm{CO} 2}\right)$ and efficiency penalty $(\Delta \eta)$ for $\mathrm{PC}$ with post-combustion $\mathrm{CO}_{2}$ capture

For IGCC with post-combustion $\mathrm{CO}_{2}$ capture case, the efficiency penalty $(\Delta \eta)$ was obtained from Equation (9), (10) and Table 8, and is expressed as Equations (15), (16) and Figure 8.

$$
\begin{gathered}
\Delta \eta=1.80 q_{\text {cap }}-0.771 \ln \left(P_{\mathrm{CO} 2}\right)+1.70 \quad\left(0 \leq q_{\text {cap }} \leq 4.21\right) \\
\Delta \eta=2.74 q_{\text {cap }}-0.771 \ln \left(P_{\mathrm{CO} 2}\right)+1.70 \quad\left(4.21<q_{\text {cap }} \leq 4.95\right)
\end{gathered}
$$




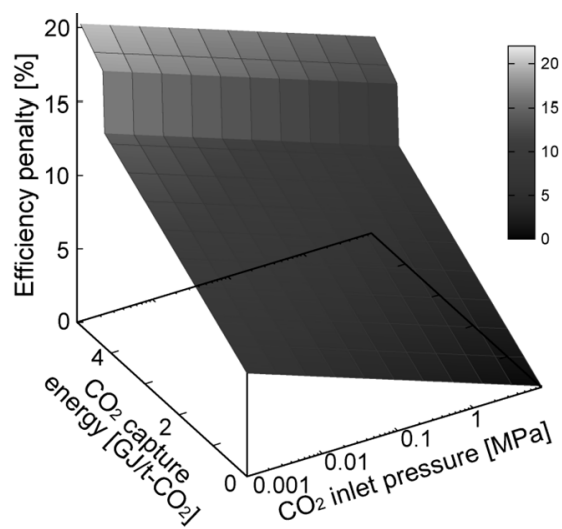

Figure 8. Relation between $\mathrm{CO}_{2}$ capture energy $\left(q_{c a p}\right), \mathrm{CO}_{2}$ inlet pressure for compressors $\left(P_{\mathrm{CO} 2}\right)$ and efficiency penalty $(\Delta \eta)$ for IGCC with post-combustion $\mathrm{CO}_{2}$ capture

For IGCC with pre-combustion $\mathrm{CO}_{2}$ capture case, the efficiency penalty $(\Delta \eta)$ was obtained from Equations (11), (12) and Table 8, and is expressed as Equations (17), (18) and Figure 9.

$$
\begin{gathered}
\Delta \eta=2.33 q_{\text {cap }}-0.770 \ln \left(P_{C O 2}\right)+1.70 \quad\left(0 \leq q_{\text {cap }} \leq 2.41\right) \\
\Delta \eta=3.42 q_{\text {cap }}-0.770 \ln \left(P_{C O 2}\right)+1.70 \quad\left(2.41<q_{\text {cap }} \leq 2.93\right)
\end{gathered}
$$

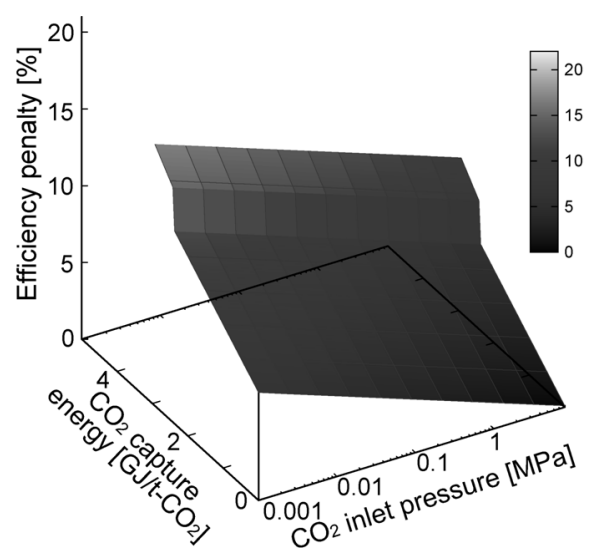

Figure 9. Relation between $\mathrm{CO}_{2}$ capture energy $\left(q_{c a p}\right), \mathrm{CO}_{2}$ inlet pressure for compressors $\left(P_{\mathrm{CO}_{2}}\right)$ and efficiency penalty $(\Delta \eta)$ for IGCC with pre-combustion $\mathrm{CO}_{2}$ capture

\subsection{Comparison With Other Studies}

The comparison of efficiency penalty reported in other studies with calculation by this study is summarized in Table 9. The calculated results show a good agreement with the reference data.

Table 9. $\mathrm{CO}_{2}$ capture conditions and efficiency penalty of literatures and calculation results

\begin{tabular}{lcccccc}
\hline Reference & $\begin{array}{c}\mathrm{CO}_{2} \text { capture } \\
\text { Technology }\end{array}$ & $\begin{array}{c}\mathrm{CO}_{2} \text { capture } \\
\text { energy } \\
{\left[\mathrm{GJ} / \mathrm{t}-\mathrm{CO}_{2}\right]}\end{array}$ & $\begin{array}{c}\text { Inlet } \\
\text { pressure } \\
{[\mathrm{MPa}]}\end{array}$ & $\begin{array}{c}\text { Efficiency } \\
\text { penalty } \\
{[\% \text {-points }]}\end{array}$ & $\begin{array}{c}\text { This study } \\
{[\% \text {-point] }}\end{array}$ & Note $^{*}$ \\
\hline NETL, 2007 & selexol & 0 & 1.2 & 1.6 & 1.6 & (b) \\
NETL, 2007 & Econamine & 3.6 & 0.16 & 9.1 & 9.4 & (a) \\
Dave, 2011 & MEA & 4.0 & $0.16^{* *}$ & 11.1 & 10.1 & (a) \\
Stöver, 2011 & MEA & 3.6 & $0.16^{* *}$ & $8.0-9.8$ & 9.4 & (a) \\
Stöver, 2011 & H3 & 2.8 & $0.16^{* *}$ & $9.9-11.2$ & 8.0 & (a) \\
\hline
\end{tabular}

*: (a) PC with post combustion $\mathrm{CO}_{2}$ capture, (b) IGCC with pre combustion $\mathrm{CO}_{2}$ capture.

**: Estimated value from the stripper temperature. 


\subsection{The Effect of Water-Gas Shift Reaction on Efficiency in IGCC}

The difference in efficiency of post- and pre-combustion $\mathrm{CO}_{2}$ capture was considered. The difference in those processes was the existence of water-gas shift reaction. There was $5.6 \%$-points of difference in the gross efficiencies of without $\mathrm{CO}_{2}$ capture (Table 3) and pre-combustion $\mathrm{CO}_{2}$ capture (Table 4) case. This was attributed to the loss of water-gas shift reaction. In case 6 or pre-combustion case, the compression energy of $\mathrm{CO}_{2}$ was $24,288 \mathrm{~kW}$, which corresponds to $0.4 \%$-points of efficiency penalty. Therefore the total efficiency penalty by $\mathrm{CO}_{2}$ capture and compression will be $6.0 \%$-points. Therefore, Equation (15) will be;

$$
q_{\text {cap }} \leq 0.428 \ln \left(P_{\mathrm{CO} 2}\right)+2.39 \quad\left(0 \leq q_{\text {cap }} \leq 4.21 \text { or } 0.00378 \leq P_{\mathrm{CO} 2} \leq 70.2\right)
$$

By solving the equation, the condition for the case 5 which would be lower than the efficiency penalty in Case 6 was obtained as Figure 10. Therefore, it can be concluded that the efficiency of IGCC with post-combustion $\mathrm{CO}_{2}$ capture will be better than that of IGCC pre-combustion process if the $\mathrm{CO}_{2}$ capture process which satisfies the painted region in Figure 10 of $\mathrm{CO}_{2}$ capture energy and $\mathrm{CO}_{2}$ inlet pressures to $\mathrm{CO}_{2}$ compressor.

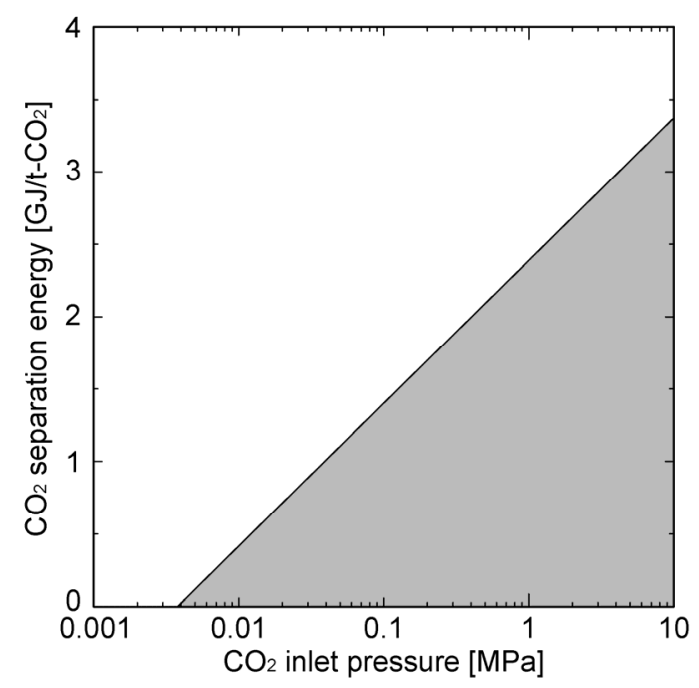

Figure 10. Relation between $\mathrm{CO}_{2}$ capture energy $\left(q_{\text {cap }}\right), \mathrm{CO}_{2}$ inlet pressure for compressors $\left(P_{\mathrm{CO} 2}\right)$ and efficiency penalty $(\Delta \eta)$ for IGCC with pre-combustion $\mathrm{CO}_{2}$ capture

\section{Conclusion}

The effects of carbon dioxide capture process on output efficiency of fossil power plants were investigated aiming to obtain a performance guideline of $\mathrm{CO}_{2}$ capture process for coal-fired power plants. The power plant models were developed by using a commercial process simulator Aspen Plus 7.3 and plant data reported from NETL. It was found that the efficiency penalty $\Delta \eta$ [\%-point] can be estimated from the $\mathrm{CO}_{2}$ capture energy $\left(q_{c a p}\right.$ $\left.\left[\mathrm{GJ} / \mathrm{t}-\mathrm{CO}_{2}\right]\right)$ and $\mathrm{CO}_{2}$ inlet pressure to the $\mathrm{CO}_{2}$ compressors $\left(P_{\mathrm{CO} 2}[\mathrm{MPa}]\right)$ by the following equations;

for PC power plant,

$\Delta \eta=1.75 q_{\text {cap }}-0.765 \ln \left(P_{C O 2}\right)+1.69$

for IGCC power plant with pre-combustion $\mathrm{CO}_{2}$ capture,

$\Delta \eta=1.80 q_{c a p}-0.771 \ln \left(P_{C O 2}\right)+1.70 \quad\left(0 \leq q_{c a p} \leq 4.21\right)$ or

$\Delta \eta=2.74 q_{\text {cap }}-0.771 \ln \left(P_{\mathrm{CO} 2}\right)+1.70 \quad\left(4.21<q_{\text {cap }} \leq 4.95\right)$

for IGCC power plant with post-combustion $\mathrm{CO}_{2}$ capture,

$$
\begin{array}{ll}
\Delta \eta=2.33 q_{\text {cap }}-0.770 \ln \left(P_{\mathrm{CO} 2}\right)+1.70 & \left(0 \leq q_{\text {cap }} \leq 2.41\right) \text { or } \\
\Delta \eta=3.42 q_{\text {cap }}-0.770 \ln \left(P_{\mathrm{CO} 2}\right)+1.70 & \left(2.41<q_{\text {cap }} \leq 2.93\right) .
\end{array}
$$

The calculated results were compared with the reference data, and they showed a good agreement.

For IGCC power plants, the effect of the installation of water-gas shift reactor on the efficiency penalty was investigated. The net efficiency was reduced 5.4 points by installing water-gas shift reactor. It was calculated that the efficiency of IGCC with post-combustion $\mathrm{CO}_{2}$ capture will be better than that of IGCC pre-combustion 
process if the $\mathrm{CO}_{2}$ capture process which satisfies the following condition;

$q_{\text {cap }} \leq 0.428 \ln \left(P_{\mathrm{CO} 2}\right)+2.39 \quad\left(0 \leq q_{\text {cap }} \leq 4.21\right.$ or $\left.0.00378 \leq P_{\mathrm{CO} 2} \leq 70.2\right)$

\section{References}

Abu Zahra, R. M. M., Fernandez, S. E., \& Goetheer, L. V. E. (2011). Guidelines for Process Development and Future Cost Reduction of $\mathrm{CO}_{2}$ Post-Combustion Capture. Energy Procedia, 4, 1051-1057. http://dx.doi.org/10.1016/j.egypro.2011.01.154

Cifre, G. P., Brechtel, K., Hoch, S., García, H., Asprion, N., Hasse, H., \& Scheffknecht, G. (2009). Integration of a chemical process model in a power plant modelling tool for the simulation of an amine based $\mathrm{CO}_{2}$ scrubber. Fuel, 88, 2481-2488. http://dx.doi.org/10.1016/j.fuel.2009.01.031

Dave, N., Do, T., Palfreyman, D., \& Feron, P. M. H. (2011). Impact of liquid absorption process development on the costs of post-combustion capture in Australian coal-fired power stations. Chemical Engineering Research and Design, 89, 1625-1638. http://dx.doi.org/10.1016/j.cherd.2010.09.010

Goto, K., Yogo, K., \& Higashii, T. (2013). A review of efficiency penalty in a coal-fired power plant with $\begin{array}{lllll}\text { post-combustion } \quad \mathrm{CO}_{2} & \text { capture. Applied } & \text { Energy, 110-720. }\end{array}$ http://dx.doi.org/10.1016/j.apenergy.2013.05.020

Intergovernmental Panel on Climate Change (IPCC). (2005). IPCC Special Report on Carbon Dioxide Capture and Storage. New York, NY: Cambridge University Press. Retrieved from http://www.ipcc.ch/pdf/special-reports/srccs/srccs_wholereport.pdf

Intergovernmental Panel on Climate Change (IPCC). (2013). Climate Change 2013 The Physical Science Basis Working Group I Contribution to the Fifth Assessment Report of the Intergovernmental Panel on Climate Change Summary for Policymakers. Retrieved from http://www.climatechange2013.org/images/uploads/WGI_AR5_SPM_brochure.pdf

International Energy Agency (IEA). (2009). World Energy Outlook. Paris, France. International Energy Agency (IEA). Retrieved from http://www.worldenergyoutlook.org/media/weowebsite/2009/WEO2009.pdf

National Energy Technology Laboratory (NETL). (2007). Cost and Performance Baseline for Fossil Energy Plants DOE/NETL-2007/1281. Retrieved from http://www.netl.doe.gov/energy-analyses/pubs/BitBase_FinRep_2007.pdf

Stöver B., Bergins, C., \& Klebes, J. (2011). Optimized Post Combustion Carbon capturing on Coal fired Power Plants. Energy Procedia, 4, 1637-1643. http://dx.doi.org/10.1016/j.egypro.2011.02.035

Strube, R., Pellegrini, G., \& Manfrida, G. (2011). The environmental impact of post-combustion $\mathrm{CO}_{2}$ capture with MEA, with aqueous ammonia, and with an aqueous ammonia-ethanol mixture for a coal-fired power plant. Energy, 36, 3763-3770. http://dx.doi.org/10.1016/j.energy.2010.12.060

\section{Copyrights}

Copyright for this article is retained by the author(s), with first publication rights granted to the journal.

This is an open-access article distributed under the terms and conditions of the Creative Commons Attribution license (http://creativecommons.org/licenses/by/3.0/). 